\title{
Acquisition and Transmissibility of U.S. Soybean dwarf virus Isolates by the Soybean Aphid, Aphis glycines
}

V. D. Damsteegt and A. L. Stone, Foreign Disease-Weed Science Research Unit, 1301 Ditto Ave., Fort Detrick, MD; M. Kuhlmann, Cell Biology \& Molecular Genetics, UMD, College Park, MD; F. E. Gildow, Department of Plant Pathology, Pennsylvania State University, State College, PA; L. L. Domier, USDA-ARS, University of Illinois, Champaign, IL; D. J. Sherman, Foreign DiseaseWeed Science Research Unit, 1301 Ditto Ave., Fort Detrick, MD; B. Tian, Department of Plant Pathology, Pennsylvania State University, State College, PA; and W. L. Schneider, Foreign Disease-Weed Science Research Unit, 1301 Ditto Ave., Fort Detrick, MD

\begin{abstract}
Damsteegt, V. D., Stone, A. L., Kuhlmann, M., Gildow, F. E., Domier, L. L., Sherman, D. J., Tian, B., and Schneider, W. L. 2011. Acquisition and transmissibility of U.S. Soybean dwarf virus isolates by the soybean aphid, Aphis glycines. Plant Dis. 95:945-950.

Soybean dwarf virus (SbDV) exists as several distinct strains based on symptomatology, vector specificity, and host range. Originally characterized Japanese isolates of SbDV were specifically transmitted by Aulacorthum solani. More recently, additional Japanese isolates and endemic U.S. isolates have been shown to be transmitted by several different aphid species. The soybean aphid, Aphis glycines, the only aphid that colonizes soybean, has been shown to be a very inefficient vector of some SbDV isolates from Japan and the United States. Trans-

mission experiments have shown that the soybean aphid can transmit certain isolates of SbDV from soybean to soybean and clover species and from clover to clover and soybean with long acquisition and inoculation access periods. Although transmission of SbDV by the soybean aphid is very inefficient, the large soybean aphid populations that develop on soybean may have epidemiological potential to produce serious SbDV-induced yield losses.
\end{abstract}

Soybean dwarf virus (SbDV) is the causal agent of an economically important disease of soybean (Glycine $\max$ (L.) Merr.) in Japan (34-37) and a minor disease of other crops elsewhere (21). The causal virus has been transmitted to more than 50 species of forage legumes, pulse crops, and other broadleaf plants representing three families $(1,5,6,18,21)$.

As a member of the Luteoviridae, SbDV is transmitted only by aphids in a circulative, persistent manner. It is phloem-limited and occurs in low concentration in plants (32). The virus consists of several distinct strains based on symptomatology in soybeans, specificity of transmission by aphid species, physiochemical properties, and nucleotide sequence $(5,27-30,37)$. The originally described Japanese soybean strains (SbDV-DS and SbDV-YS), hereinafter called SbDV-D and SbDV-Y, and a subterranean clover red-leaf virus (SCRLV, now synonymous with SbDV) described in Australia (20) were transmitted almost exclusively by Aulacorthum solani Kaltenbach. An isolate serologically related to SCRLV found in California (19), and other related isolates found worldwide, were transmitted by Acyrthosiphon pisum (Harris) and other aphid species $(7,11,16,22,23)$, and not by $A$. solani. More recently, dwarfing and yellowing strains of SbDV (SbDV-DP and SbDV-YP) have been described from Japan that were transmitted by Acyrthosiphon pisum (37). Except for one report (15), all earlier attempts to transmit strains of SbDV by the soybean aphid Aphis glycines Matsumora have been unsuccessful $(11,32,41)$. The soybean aphid has been reported to transmit several plant viruses $(4,11)$ including the Indonesian Soybean dwarf virus (17). The Indonesian SbDV was shown to be serologically distinct from Japanese SbDV isolates, and no further reports about this virus could be found.

Corresponding author: V. D. Damsteegt,

E-mail: vern.damsteegt @ars.usda.gov

Accepted for publication 1 March 2011.

doi:10.1094/PDIS-10-10-0726

This article is in the public domain and not copyrightable. It may be freely reprinted with customary crediting of the source. The American Phytopathological Society, 2011.
In 2000, the soybean aphid was first reported in the United States in Wisconsin (3), and it has since spread throughout most soybean-producing regions in North America east of the Rocky Mountains. Heavy infestations of soybean aphids often produce severely dwarfed plants with cupped, dark green, or yellowed leaves that resemble the symptoms induced by SbDV (13). Consequently, a link between the presence of Aphis glycines and SbDV infection was suspected. In both Japan and the United States, conflicting reports have been published on the ability of $A$. glycines to transmit SbDV $(11,15,34,36,38,41)$. In order to clearly determine possible connections between SbDV reports and the presence of the soybean aphid, extensive transmission experiments were conducted using several U.S. and Japanese isolates of SbDV. We report that endemic strains of SbDV are inefficiently transmitted by $A$. glycines and that length of acquisition and inoculation access periods affect transmission efficiency.

\section{Materials and Methods}

Virus isolates, aphid populations, and host plants. Populations of Aphis glycines were collected during field surveys in Illinois, Maryland, and Pennsylvania. Aphid identities were confirmed by Doris Lagos and David Voegtlin, University of Illinois, and Susan Halbert, Florida Department of Agriculture, Gainesville. These aphid populations were maintained on soybean 'Williams 82' and a glabrous soybean line (PI 547502), from Glen Hartman (IL), in the BSL-3 biosecurity containment facility at Fort Detrick, MD. Cages with aphids were maintained at 24 to $26^{\circ} \mathrm{C}, 16 \mathrm{~h} \mathrm{D} / \mathrm{N}$ with natural and supplemental lighting. Each aphid population was established by nymphal deposit (nymphs separated from adult aphids upon birth and moved to healthy soybean plants for two consecutive transfers) and assayed at each transfer for the presence of contaminating luteoviruses by enzyme-linked immunosorbent assay (ELISA).

Japanese dwarfing and yellowing isolates of SbDV, SbDV-D and SbDV-Y, respectively, were obtained in 1981 from Hokkaido, Japan, and a closely related strain in 1986 from Christchurch, New Zealand. In addition, 13 endemic SbDV isolates from black medic (Medicago lupulina L.), Chenopodium sp., red clover (Trifolium pratense L.), soybean, subterranean clover (T. subterraneum L.), and white clover (T. repens L.) were obtained from two U.S. mid- 
Atlantic $(6,7)$ and one midwestern state (11). These isolates were used in transmission studies with A. glycines (Table 1). Endemic $\mathrm{SbDV}$ isolates were characterized as SbDV based on biological and molecular similarities to originally characterized SbDV strains $(9,12,31,37)$. Isolates were routinely transferred with $A$. pisum (pea aphid), Myzus persicae (Sulzer) (green peach aphid), and/or Nearctaphis bakeri (Cowen) (short-beaked clover aphid) $(7,11)$. Some isolates closely align with the dwarfing genotype of SbDV$\mathrm{D}$, some with the yellowing genotype SbDV-Y, and some were coinfected with both genotypes (28).

Transmission experiments. Initial transmission experiments were conducted by placing hundreds of non-viruliferous A. glycines aphids on detached leaves of young soybean and subterranean clover plants that were infected with Japanese SbDV-D, SbDV-Y, and endemic isolates MD3, MD8, MD9, and VA20 for a 48-h acquisition access period (AAP). Leaves bearing 50 or more aphids then were placed in cylindrical cages over unifoliolate Williams 82 soybean seedlings or clover seedlings for a 48-h inoculation access period (IAP), after which aphids were killed by insecticidal sprays. Inoculated plants were periodically examined for symptoms for 4 weeks before being tested by ELISA and/or reverse transcription-polymerase chain reaction (RT-PCR) for the presence of virus.

Following demonstration of transmission of two endemic SbDV isolates (8), transmission experiments were conducted with additional endemic isolates obtained from red clover, soybeans, and white clover during field surveys from 2005 to 2008 in Maryland and Illinois, using comparable inoculation parameters (Table 1). Known virus/vector combinations (A. pisum, $M$. persicae, or $N$. bakeri with endemic SbDV isolates and A. solani with Japanese and New Zealand isolates) served as positive controls, and healthy aphids feeding on healthy soybean seedlings served as negative controls with each experiment. Isolates, aphid vectors, and test plants were kept separated in time and space to prevent possible cross-contamination. Each transmission experiment was repeated at least three times with varying transmission parameters.
Short versus long AAP/IAP transmission experiments. Routine acquisition and inoculation access periods for SbDV are 24 or $48 \mathrm{~h}$. However, because of inconsistencies in transmission of SbDV by $A$. glycines utilizing these time parameters, experiments were conducted with lengthened AAPs and IAPs. A series of trials were conducted lengthening the AAP from $48 \mathrm{~h}$ to 7 to 14 days and the IAP from $48 \mathrm{~h}$ to 10 to 30 days using hundreds of aphids. Nonviruliferous A. glycines were allowed to colonize SbDV-infected, symptomatic soybean plants for 7 to 14 days and then permitted to move naturally from the infected plants to healthy soybean seedlings in large cages over a 10 to 30 day IAP. After the IAPs, the plants were sprayed with insecticide to kill the aphids, monitored by visual inspection 30 days for symptom development, and then assayed by ELISA and/or RT-PCR for the presence of the virus.

Following successful transmission of SbDV isolates by A. glycines with lengthened AAPs and IAPs, serial passages were attempted within the same inoculated species or between species. At least 25 to 50 or more A. glycines were used per seedling with AAPs and IAPs of at least 7 to 10 days. Test plants were observed for symptoms and assayed by ELISA and/or RT-PCR.

Immunological and molecular assays. Confirmation of the presence of SbDV in inoculated plants was accomplished by ELISA, conventional, and/or real-time RT-PCR. ELISA was performed using a commercially available kit according to manufacturer's directions (Agdia).

For conventional RT-PCR, total nucleic acids were extracted from inoculated plants as previously described (40). SbDV RNA was amplified using first-strand cDNA synthesis as follows: $2 \mu \mathrm{l}$ of total nucleic acid was added to $1 \times$ first strand buffer (Invitrogen), $10 \mathrm{mM}$ DTT, $300 \mu \mathrm{M}$ dNTP mix, $200 \mathrm{nM}$ SbDV 3R (5' GGT ACA CCA CTA TTC AAG AT $3^{\prime}$ ), and 40 U SuperScript II (Invitrogen). The reaction was incubated at $42^{\circ} \mathrm{C}$ for $2.5 \mathrm{~h}$. Amplification followed using $1 \mu \mathrm{l}$ of the first strand reaction with $1 \times$ Reaction Buffer (QIAGEN), $200 \mu \mathrm{M}$ dNTP mix, $200 \mathrm{nM}$ SbDV 4F (5' GAG GGG CTC TGC TCC GAC TCT G 3'), 200 nM SbDV 5R (5' CGT TCA ACC GCC ACC AAT GC 3'), and $0.5 \mathrm{U}$ Taq polymerase (QIAGEN). The reaction conditions were: $94^{\circ} \mathrm{C}$ for $3 \mathrm{~min}$, then 35

Table 1. Nomenclature of Soybean dwarf virus isolates included in Aphis glycines transmission study

\begin{tabular}{|c|c|c|c|c|}
\hline Isolate & Strain(s) & Source host & Location & Contributor \\
\hline SbDV-D(1981) & $\mathrm{D}^{\mathrm{a}}$ & Soybean & Naganuma, Japan & $\begin{array}{l}\text { T. Tamada } \\
\text { U51448 }\end{array}$ \\
\hline SbDV-Y (1981) & $\mathrm{Y}^{\mathrm{a}}$ & Soybean & Naganuma, Japan & $\begin{array}{l}\text { T. Tamada } \\
\text { L20835 }\end{array}$ \\
\hline SbDV-NZ (1986) & $\mathrm{Y}$ & White clover & Christchurch, New Zealand & $\begin{array}{l}\text { J. W. Ashby } \\
\text { JF288563 }\end{array}$ \\
\hline MD1 (1986) & $\mathrm{Y}$ & White clover & Fort Detrick, MD & $\begin{array}{l}\text { V. D. Damsteegt } \\
\text { EU306577 }\end{array}$ \\
\hline MD2 (1991) & $\mathrm{D}, \mathrm{Y}$ & White clover & Anne Arundel Co, MD & $\begin{array}{l}\text { A. L. Stone } \\
\text { EU306578, EU306579 }\end{array}$ \\
\hline MD3 (1991) & $\mathrm{D}$ & Chenopodium sp. & Washington Co., MD & $\begin{array}{l}\text { A. L. Stone } \\
\text { EU306580 }\end{array}$ \\
\hline MD6 (2005) & $\mathrm{Y}$ & White clover & Prince George's Co., MD & $\begin{array}{l}\text { F. E. Gildow } \\
\text { JF293280 }\end{array}$ \\
\hline MD8 (1988) & $\mathrm{D}, \mathrm{Y}$ & Black medic & Howard Co., MD & $\begin{array}{l}\text { A. L. Stone } \\
\text { EU306582, EU306583 }\end{array}$ \\
\hline MD9 (2005) & $\mathrm{D}$ & Red clover & Howard Co., MD & $\begin{array}{l}\text { A. L. Stone } \\
\text { EU306591 }\end{array}$ \\
\hline MD10 (2006) & $\mathrm{Y}$ & White clover & Prince George's Co., MD & $\begin{array}{l}\text { V. D. Damsteegt } \\
\text { JF288562 }\end{array}$ \\
\hline MD11 (2006) & $\mathrm{D}$ & Soybean & Howard Co., MD & $\begin{array}{l}\text { A. L. Stone } \\
\text { JF288561 }\end{array}$ \\
\hline MD16 (2006) & $\mathrm{Y}$ & White clover & Prince George's Co., MD & $\begin{array}{l}\text { W. L. Schneider } \\
\text { JF303084 }\end{array}$ \\
\hline VA20 (1990) & $\mathrm{D}, \mathrm{Y}$ & Subterranean clover & Blacksburg, VA & $\begin{array}{l}\text { S. A. Tolin } \\
\text { EU306589, EU306590 }\end{array}$ \\
\hline ClAgt1 (2007) & $\mathrm{D}$ & Red clover & Champaign Co., IL & $\begin{array}{l}\text { L. L. Domier } \\
\text { EU419584 }\end{array}$ \\
\hline ClAgt2 (2007) & $\mathrm{D}$ & Red clover & Champaign Co., IL & $\begin{array}{l}\text { L. L. Domier } \\
\text { EU419583 }\end{array}$ \\
\hline CL08 (2008) & $\mathrm{D}$ & Red clover & Champaign Co., IL & L. L. Domier \\
\hline
\end{tabular}

a Originally characterized Japanese dwarfing (D) and yellowing (Y) strains. 
cycles of $94^{\circ} \mathrm{C}$ for $30 \mathrm{~s}, 57^{\circ} \mathrm{C}$ for $45 \mathrm{~s}$, and $72^{\circ} \mathrm{C}$ for $45 \mathrm{~s}$, followed by a final $72^{\circ} \mathrm{C}$ extension for $5 \mathrm{~min}$.

For real-time RT-PCR reactions, the primer SbDV 1880R (5' CAT TTA TTG GCT ATT ATC TTC C $3^{\prime}$ ) was used to prime reverse transcription reactions using the same conditions described above. Following reverse transcription, $1 \mu \mathrm{l}$ of first strand reaction with $1 \times$ Reaction Buffer (QIAGEN), $200 \mu \mathrm{M}$ dNTP mix, a total of $6 \mathrm{mM} \mathrm{MgCl}_{2}, 1 \times \mathrm{Smart}_{\mathrm{Cycler}}$ additive reagent, $1.25 \mathrm{U} \mathrm{Taq}$ polymerase (QIAGEN), $200 \mathrm{nM}$ SbDV 1880R, $200 \mathrm{nM}$ SbDV 1548F-D (5' GGA YAA GGT TGG TTG YCC TAG GAC GGT 3') or SbDV 1548F-Y (5' GGA YAA GGT TGG TTG GYC CTA GGA CGT T $\left.3^{\prime}\right)$, and $100 \mathrm{nM}$ SbDV 1728 probe (5' FAM-GAT AGC ACC CAG GTT GAT ATG TCT C-BHQ 3'). The reactions were run in a SmartCycler (Cepheid) machine with the following conditions: $95^{\circ} \mathrm{C}$ for $10 \mathrm{~min}$, then 45 cycles of $95^{\circ} \mathrm{C}$ for $15 \mathrm{~s}$ and $60^{\circ} \mathrm{C}$ for 1 min. Assay positive result threshold was calculated by the SmartCycler program using 10 standard deviations above background fluorescence.

Persistence of SbDV in aphids following acquisition. The endemic MD16 and VA20 isolates, and Japanese D and Y strains were used to test the amount of SbDV acquired and retained by $A$. glycines and A. solani. The A. glycines colony of aphids was reared on soybean, and the $A$. solani colony was reared on curly dock (Rumex crispus L.). The SbDV-infected source soybeans were first assayed to determine the titers of SbDV. Approximately 100 aphids were placed on detached leaves for a 24 to $48 \mathrm{~h}$ AAP. Following the AAP, 15 aphids were placed into $1.5-\mathrm{ml}$ tubes with two leaf disks from a healthy plant and flash frozen using liquid nitrogen. The remaining aphids were transferred to detached leaves of curly dock, nonhost of SbDV, and allowed to feed for 24 to $48 \mathrm{~h}$ to clear the gut. After 24 to $48 \mathrm{~h}$, aphids were sampled as before. Total nucleic acids were extracted from the flash frozen aphid samples according to Ali et al. (2), and real-time RT-PCR was performed as described above. Four replicate experiments were conducted using A. glycines, and three replicate experiments were conducted using A. solani.

\section{Results}

Transmission experiments. The transmissibility of $16 \mathrm{SbDV}$ isolates was initially determined using a detached leaf method. Thirteen of these isolates were from the United States (ClAgt1, ClAgt2, CL08, MD1, MD2, MD3, MD6, MD8, MD9, MD11, MD16, and VA20), two from Japan (D and Y), and one from New Zealand (NZ) (Table 1). All transmission experiments using $A$. glycines with Japanese SbDV-D and NZ from New Zealand were negative (Table 2), but these isolates were efficiently transmitted by $A$. solani. The SbDV-Y strain was inefficiently transmitted $(<2 \%)$ with lengthened AAP and IAP. None of the U.S. isolates were transmitted by $A$. solani, except for infrequent $(<2 \%)$ transmission of VA20, some were transmitted by A. glycines, and all isolates that were tested were found to be transmissible by $A$. pisum and $M$. persicae. All Illinois isolates were transmitted by $N$. bakeri and all Maryland isolates that were tested with $N$. bakeri were transmitted; however, not all isolates were tested (Table 2).

Less than $5 \%$ of the initial A. glycines transmissions conducted with ClAgt1, ClAgt2, CL08, MD8, and VA20 utilizing 24 to $48 \mathrm{~h}$ AAPs and IAPs were positive, and additional transmission experiments with these isolates were often negative. To increase the efficiency of transmission, aphids were allowed to acquire virus from whole infected plants rather than from detached leaves. Acquisition and inoculation access periods up to $48 \mathrm{~h}$ on whole plants did not increase transmission success. When the AAP was lengthened from $48 \mathrm{~h}$ to 7 to 14 days and the IAP from $48 \mathrm{~h}$ to 21 days on whole plants (not possible with detached leaves), A. glycines transmission rates increased (Table 3). Lengthening the AAP beyond 7 days and the IAP beyond 21 days did not increase transmission rates (data not shown).

The endemic isolates were transmitted by A. glycines from clover species to soybean, from soybean to soybean, and from soybean to clover species. Serial transmissions of ClAgt1, ClAgt2, and CL08 were successful through four passages using A. glycines as the vector on soybean; however, transmissions of MD6, MD10, and VA20 were lost after two to four passages.

Symptoms produced by the different isolates transmitted by $A$. glycines were similar to reported symptoms produced by Japanese SbDV strains transmitted by A. pisum (37) or endemic U.S. isolates $(7,11)$ when transmitted by A. pisum, M. persicae, or $N$. bakeri. Some isolates produced only mild stunting and dark green leaves (D-type), others produced little stunting with characteristic interveinal yellowing (Y-type), and some isolates produced both phenotypes (mixed D and Y) (Table 1).

Persistence of SbDV in aphids following acquisition. A limited number of isolates from the original transmission studies were used to test the amount of SbDV acquired by A. glycines and $A$. solani. The original Japanese D was transmissible by A. solani but not by $A$. glycines, the original Japanese $\mathrm{Y}$ was transmissible by $A$ solani and A. glycines (low levels), the MD16 isolate was transmissible by A. glycines but not A. solani, and the VA20 isolate was

Table 2. Qualitative aphid transmission of U.S. and Japanese Soybean dwarf virus isolates by Aphis glycines and other reported aphid vectors ${ }^{\mathrm{a}}$

\begin{tabular}{|c|c|c|c|c|c|}
\hline \multirow[b]{2}{*}{ Isolate/strain } & \multicolumn{5}{|c|}{ Aphid species } \\
\hline & A. glycines & Acyrthosiphon pisum & Aulacorthum solani & Myzus persicae & Nearctaphis baker \\
\hline \multicolumn{6}{|l|}{ Exotic isolates } \\
\hline SbDV-D & $-^{\mathrm{b}}$ & - & $t^{\mathrm{b}}$ & - & $\mathrm{ND}^{\mathrm{b}}$ \\
\hline SbDV-Y & $+^{\mathrm{c}}$ & - & + & - & ND \\
\hline SbDV-NZ & - & - & + & - & ND \\
\hline \multicolumn{6}{|c|}{ Endemic isolates } \\
\hline MD1 & - & + & ND & + & ND \\
\hline MD2 & ND & + & ND & + & + \\
\hline MD3 & - & + & ND & + & ND \\
\hline MD6 & + & + & - & + & + \\
\hline MD8 & + & + & ND & + & ND \\
\hline MD9 & - & + & ND & + & + \\
\hline MD10 & + & + & - & + & ND \\
\hline MD11 & + & + & ND & ND & ND \\
\hline MD16 & + & + & - & + & + \\
\hline VA20 & + & + & $t^{\mathrm{c}}$ & + & + \\
\hline ClAgt1 & + & ND & ND & ND & + \\
\hline ClAgt2 & + & ND & ND & ND & + \\
\hline CL08 & + & ND & ND & ND & + \\
\hline
\end{tabular}

${ }^{\text {a }}$ More than 25 aphids were used per isolate/plant with each transmission experiment. Not all possible aphid/isolate combinations were completed; most transmission experiments utilized $48 \mathrm{~h}$ acquisition access period/48 $\mathrm{h}$ inoculation access period.

${ }^{\mathrm{b}} \mathrm{ND}=$ not determined, + indicates positive infection, - indicates negative results.

c Very infrequent transmission $<2 \%$. 
transmissible by A. glycines and A. solani (low levels). Virus titers in source soybean leaves varied with $\mathrm{Ct}$ values ranging from 19.7 to 30.1 (data not shown). The PCR reaction limits of detection for $\mathrm{D}$ and $\mathrm{Y}$ assays approximates $5 \mathrm{fg}$ or a $\mathrm{Ct}$ value of 38 . The Japanese isolates were acquired by $A$. solani, and the virus was present after 24 to $48 \mathrm{~h}$ on the nonhost (Table 4), suggesting the virus had successfully transitioned to the hemocoel and/or accessory salivary gland. The Japanese isolates also were acquired by A. glycines, but only the Japanese $\mathrm{Y}$ isolate was retained at low levels after the nonhost feed. The endemic isolate MD16 was acquired by both aphid species, but was only retained by A. glycines. Endemic VA20 was acquired and retained by both aphid species. Interestingly, the $\mathrm{Y}$ component of the VA20 mixed infection was only acquired and retained by A. glycines in one of four replicate experiments. The Y component of the VA20 mixed infection exists at lower titers than

Table 3. Transmission efficiency of Soybean dwarf virus (SbDV) isolates VA20 and ClAgt1 by Aphis glycines using short and long acquisition access periods (AAP) and inoculation access periods (IAP)

\begin{tabular}{|c|c|c|c|}
\hline \multirow[b]{2}{*}{ Experiment } & \multicolumn{2}{|c|}{ SbDV-VA20 ${ }^{a}$} & \multirow{2}{*}{$\begin{array}{c}\text { SbDV-ClAgt1 }^{\text {b }} \\
\text { AAP } 7 \text { day+/ } \\
\text { IAP } 21 \text { day+ }\end{array}$} \\
\hline & $\begin{array}{l}\text { AAP } 48 \mathrm{~h} / \\
\text { IAP } 48 \mathrm{~h}\end{array}$ & $\begin{array}{l}\text { AAP } 7 \text { day+l } \\
\text { IAP } 21 \text { day+ }\end{array}$ & \\
\hline 1 & $1 / 20^{c}$ & & \\
\hline 2 & $0 / 20$ & & \\
\hline 3 & $4 / 20$ & & \\
\hline 4 & $0 / 20$ & & \\
\hline 5 & & $3 / 20$ & \\
\hline 6 & & $4 / 20$ & \\
\hline 7 & & $5 / 20$ & \\
\hline 8 & & $3 / 20$ & \\
\hline 9 & & & $4 / 10$ \\
\hline 10 & & & $7 / 24$ \\
\hline 11 & & & $13 / 76$ \\
\hline 12 & & & $1 / 61$ \\
\hline 13 & & & $2 / 15$ \\
\hline Total & $5 / 80(6.3 \%)$ & $18 / 80(18.7 \%)$ & $27 / 186(14.5 \%)$ \\
\hline
\end{tabular}

${ }^{\text {a }}$ Experiments utilized 25 to 50 A. glycines per soybean seedling. Reaction based on symptoms and/or enzyme-linked immunosorbent assay (ELISA) results.

${ }^{\mathrm{b}}$ Experiments utilized 10 to 20 A. glycines per soybean seedling. Reaction based on ELISA results.

${ }^{\mathrm{c}}$ Number positive for SbDV infection/number soybean seedlings tested. the D component in VA20 infected plants (data not shown), and was never acquired by $A$. solani.

\section{Discussion}

Soybean dwarf virus disease was described in Japan (33) as having dwarfing and yellowing strains. Both strains were transmitted specifically by A. solani (32). Other isolates found in many countries, including the United States, had similar symptomatology, similar hosts, and were transmitted by A. pisum, M. persicae, $N$. bakeri, and other aphid species but were not transmitted by $A$. solani. In 2001, additional isolates of SbDV were described from Japan (37) that were transmissible by A. pisum but not by A. solani. In all earlier studies $A$. glycines was always reported as a pest of soybean (the only aphid colonizing soybean) that did not transmit SbDV except for one report (15). This indicated that transmission by A. glycines was rare.

The soybean aphid was reported in the United States in 2000 $(3,26)$ and has spread to more than 20 states and Canada. Published reports from surveys for A. glycines and possible viruses transmitted by $A$. glycines indicated that it was a vector of several soybean infecting viruses $(4,41)$ but not SbDV. Surveys for soybean diseases in Illinois and Wisconsin $(24,25,39)$ indicated the occurrence of SbDV in some areas, but these occurrences were not linked to disease symptoms or to the presence of A. glycines. The majority of reports in the literature have suggested that the A. glycines/SbDV vector/virus relationship was a rare possibility at best.

A. glycines were collected from multiple field locations in Illinois, Maryland, and Pennsylvania, and maintained as colonies. These colonies were tested as potential vectors for some endemic isolates of SbDV with the hypothesis that because endemic SbDV isolates had very different vector specificities from the original Japanese SbDV strains (32), they might be transmissible by $A$. glycines. Three independent laboratories in Illinois, Maryland, and Pennsylvania achieved successful transmission with several endemic isolates. However, the level of transmission success was low or completely absent for endemic isolates even though large numbers of aphids were used per seedling. Endemic SbDV isolates were efficiently transmitted at high levels by A. pisum, M. persicae, and/or $N$. bakeri using 10 to 25 aphids per seedling (Table 2 and data not shown). In contrast, the Japanese and New Zealand isolates of SbDV were highly transmissible by as few as 1 to $2 \mathrm{~A}$.

Table 4. Acquisition and retention of Soybean dwarf virus (SbDV) endemic isolates MD16, VA20, and Japanese isolates D and Y by Aphis glycines and Aulacorthum solani

\begin{tabular}{|c|c|c|c|c|c|c|c|c|}
\hline \multirow[b]{2}{*}{ Isolate } & \multirow[b]{2}{*}{ Source } & \multirow[b]{2}{*}{ Vector } & \multicolumn{2}{|c|}{ Acquisition and retention $^{\mathrm{a}}$} & \multicolumn{2}{|c|}{ SbDV source aphid Ct values ${ }^{b}$} & \multicolumn{2}{|c|}{ Nonhost aphid Ct values } \\
\hline & & & D & $\mathbf{Y}$ & D & $\mathbf{Y}$ & D & $\mathbf{Y}$ \\
\hline \multirow[t]{4}{*}{ VA20 } & Soybean & A. glycines & $4 / 4$ & $1 / 4$ & 29.1 & 41.7 & 32.5 & 37.4 \\
\hline & & & $3 / 4$ & $1 / 4$ & $+/-2.9$ & $+/-0.0$ & $+/-1.3$ & $+/-0.0$ \\
\hline & & A. solani & $3 / 3$ & $0 / 3$ & 22.0 & - & 27.5 & - \\
\hline & & & $2 / 3$ & $0 / 3$ & $+/-1.3$ & & $+/-1.9$ & \\
\hline \multirow[t]{4}{*}{ MD16 } & Soybean & A. glycines & $\mathrm{NA}^{\mathrm{c}}$ & $2 / 3$ & NA & 31.4 & NA & 29.8 \\
\hline & & & & $2 / 3$ & & $+/-0.9$ & & $+/-2.1$ \\
\hline & & A. solani & NA & $1 / 3$ & NA & 28.0 & NA & - \\
\hline & & & & $0 / 3$ & & $+/-0.0$ & & \\
\hline \multirow[t]{4}{*}{ Japan D } & Soybean & A. glycines & $3 / 4$ & NA & 28.2 & NA & - & NA \\
\hline & & & $0 / 4$ & & $+/-2.7$ & & & \\
\hline & & A. solani & $2 / 3$ & NA & 30.9 & NA & 29.4 & NA \\
\hline & & & $2 / 3$ & & $+/-10.6$ & & $+/-0.5$ & \\
\hline \multirow[t]{4}{*}{ Japan Y } & Soybean & A. glycines & NA & $4 / 4$ & NA & 31.9 & NA & 35.5 \\
\hline & & & & $3 / 4$ & & $+/-4.4$ & & $+/-3.5$ \\
\hline & & A. solani & NA & $3 / 3$ & NA & 33.9 & NA & 31.1 \\
\hline & & & & $2 / 3$ & & $+/-5.0$ & & $+/-1.1$ \\
\hline
\end{tabular}

\footnotetext{
${ }^{a}$ Acquisition and retention values represented by two fractions. The top fraction represents the number of times the aphid acquired the virus from feeding on infected host tissue/total number of experimental repetitions. The bottom fraction represents the number of times the aphid retained the virus after feeding on noninfected nonhost tissue/total number of experimental repetitions.

${ }^{\mathrm{b}}$ Mean $\mathrm{Ct}$ values for all positive results with standard deviations. In cases where only a single sample tested positive, the standard deviation is listed as 0.0 . The polymerase chain reaction limits of detection are near $5 \mathrm{fg}$ for both $\mathrm{D}$ and $\mathrm{Y}$ assays (typical $5 \mathrm{fg}=\mathrm{Ct}$ values around 38). Negative reactions indicated by $(-)$.

${ }^{\mathrm{c}}$ Not applicable.
} 
solani aphids per seedling, but were not transmitted by A. glycines or by any of the other aphid species tested.

The inconsistency of transmission of a circulative virus could be due to barriers to virus transmission through the gut into the hemocoel, or to virus accumulation in accessory salivary glands $(9,10)$. The low efficiency and sometimes lack of SbDV transmission by A. glycines also could be due to feeding behavior or other unspecified factors. Efforts to improve the efficiency of A. glycines transmission of endemic SbDV isolates met with mixed results. Using whole plants as source tissue instead of detached leaves made no difference when the AAP and IAP were 24 to $48 \mathrm{~h}$. Simply increasing the numbers of aphids used was ineffective. The soybean aphid colonizes soybeans very readily with huge numbers per plant, and the use of 100 aphids per unifoliolate seedling was deleterious to the seedlings. However, when longer AAPs of 7 days on young, infected soybeans were followed by 21-day IAPs on seedlings in the second trifoliolate stage or later, A. glycines transmission improved dramatically and became more consistent (Table 3 ). The symptoms produced by the A. glycines-transmitted endemic isolates were typical of those produced on plants that had A. pisum, M. persicae, or N. bakeri as the vector. Interestingly, when A. glycines was given lengthened AAPs and IAPs on soybean infected with the Japanese Y strain, up to $2 \%$ infection rates could be obtained, indicating that if given sufficient interaction with soybeans infected with the $\mathrm{Y}$ strain, some transmission would be possible. This pattern was true also for $A$. solani with at least one endemic isolate, VA20 (Table 2).

Two Japanese SbDV strains and two endemic SbDV isolates in soybean were used to test the acquisition of SbDV by vector and nonvector species. The Japanese D isolate is A. solani transmissible, the MD16 isolate is A. glycines transmissible, and the VA20 and Japanese $\mathrm{Y}$ isolates are transmissible by both vectors. Both $A$. glycines and A. solani acquired all the isolates tested while feeding on the infected source tissue. However, the retention of the virus through the nonhost feed was correlated to the ability of the aphid to vector the strain used. For example, Japanese D and MD16 were acquired by the nonvector aphid species but never retained. Presumably the virus detected in the aphids feeding on infected host tissue was largely present in the gut, and not necessarily available for transmission. In the nonvector, no virus was detected after the nonhost feed, suggesting that none of the virus crossed the gut barrier. The Japanese $\mathrm{Y}$ isolate was acquired and retained by $A$. glycines at low levels, suggesting that a limited amount of the Japanese $\mathrm{Y}$ viral particles had crossed the gut barrier into the hemocoel and possibly the accessory salivary gland. However, the rarity of transmission of Japanese Y by A. glycines may indicate that successful movement from the gut through the hemocoel into the salivary gland may be restricted. There is no transmission of Japanese $\mathrm{Y}$ with short (48 h) AAPs and IAPs, but transmission is possible with long AAPs and IAPs, which further supports this hypothesis.

The endemic isolate VA20 is a mixture of D and Y strains, but following feeding on infected soybeans, only A. glycines (the vector) had any traces of the SbDV-Y component. The SbDV-D component was detected in both aphid species from both host feedings. Following the nonhost feeding, both D and Y components of VA20 were only detected in A. glycines that had fed on soybeans, but not in the A. solani feeding samples. However, the D component of the VA20 mixed infection was acquired and retained by both A. solani and A. glycines. This contrast is interesting in light of the fact that both aphid species have been known to transmit both components of the mixed infection in previous experiments (Table 2 and data not shown). It should be noted that the acquisition times for the persistence experiments are much shorter that the acquisition times for the transmission efficiency testing. This may affect the results for all the isolates tested. In addition, the ratio of $\mathrm{D}$ to $\mathrm{Y}$ components in VA20-infected soybeans is regularly biased toward the D component. Perhaps the negative result here is simply a failure to detect marginal amounts of virus.

As seen in Table 2, not all endemic isolates are transmitted by $A$. glycines, and none are transmitted efficiently. In addition, serial transmission of endemic isolates from one soybean to another could not be maintained indefinitely. Several transmission experiments were lost after two serial transmissions, but others were carried through four transfers. Whether the loss of serial transmission would indicate an impediment to the development of an $A$. glycines vectored epidemic requires further study. The soybean aphid has been shown to colonize red clover but does not survive on white clover. Isolates of SbDV in the Midwest are D-like and known to infect red clover $(11,41)$, while most isolates found in mid-Atlantic states are Y-like or mixed D and $\mathrm{Y}$ and found in white clover (7) (Table 1). Isolates obtained from red clover in eastern states $(7,28)$ also were found to be D-like, similar to Midwest isolates. The preference of $A$. glycines for red clover may be significant in the epidemiology of SbDV since it may serve as an alternative host for SbDV, especially SbDV-D.

The soybean aphid has been in soybean fields in the United States for 10 years, and soybean dwarf infected plants have been found at a low percentage each year (24). Although SbDV has the ability to be a devastating disease and an aphid vector that colonizes soybean is now present in the United States, we have not seen evidence of a marked increase in SbDV incidence in soybean production fields $(14,38)$.

\section{Acknowledgments}

The authors wish to acknowledge the contributions of Bill Sacchet (PSU), Allison Younkins, and Ann Echard (FDWSR) for aphid and plant handling and data collection. Mention of a trademark, proprietary product, or vendor does not constitute a guarantee or warranty of the product by the USDA or the University of Illinois and does not imply its approval to the exclusion of other products or vendors that may also be suitable.

\section{Literature Cited}

1. Abraham, A. D., Menzel, W., Vetten, H. J., and Saucke, H. 2007. First report of Soybean dwarf virus (Genus Luteovirus) infecting Faba bean and clover in Germany. Plant Dis. 91:1059.

2. Ali, A., Li, H., Schneider, W. L., Sherman, D. J., Gray, S., Smith, D., and Roossinck, M. J. 2006. Analysis of genetic bottlenecks during horizontal transmission of Cucumber mosaic virus. J. Virol. 80:8345-8350.

3. Alleman, R. J., Grau, C. R., and Hogg, D. B. 2002. Soybean aphid host range and virus transmission efficiency. Online publication. Proc. 2002 Wisconsin Fertilizer, Aglime, and Pest Mgmt. Conf.

4. Clark, A. J., and Perry, K. L. 2002. Transmissibility of field isolates of soybean viruses by Aphis glycines. Plant Dis. 86:1219-1222.

5. Damsteegt, V. D., Hewings, A. D., and Sindermann, A. B. 1990. Soybean dwarf virus: Experimental host range, soybean germplasm reactions, and assessment of potential threat to U.S. soybean production. Plant Dis. 74:992-995.

6. Damsteegt, V. D., Stone, A. L., and Hewings, A. D. 1995. Soybean dwarf, bean leaf roll, and beet western yellows luteoviruses in southeastern U.S. white clover. Plant Dis. 79:48-50.

7. Damsteegt, V. D., Stone, A. L., Russo, A. J., Luster, D. G., Gildow, F. E., and Smith, O. P. 1999. Identification, characterization, and relatedness of luteovirus isolates from forage legumes. Phytopathology 89:374-379.

8. Damsteegt, V. D., Stone, A. L., Schneider, W. L., Sherman, D. J., Gildow, F. E., and Luster, D. G. 2005. The soybean aphid, Aphis glycines, a new vector of endemic dwarfing and yellowing isolates of Soybean dwarf luteovirus. (Abstr.) Phytopathology 95:S22.

9. Gildow, F. E., Damsteegt, V. D., Stone, A. L., Smith, O. P., and Gray, S. M. 2000. Virus-vector cell interactions regulating transmission specificity of Soybean dwarf luteoviruses. J. Phytopathol. 148:333-342.

10. Gray, S., and Gildow, F. E. 2003. Luteovirus-aphid interactions. Annu. Rev Phytopathol. 41:539-566.

11. Harrison, B., Steinlage, T. A., Domier, L. L., and D'Arcy, C. J. 2005. Incidence of Soybean dwarf virus and identification of potential vectors in Illinois. Plant Dis. 89:28-32.

12. Hewings, A. D., Damsteegt, V. D., and Tolin, S. A. 1986. Purification and some properties of two strains of Soybean dwarf virus. Phytopathology 76:759-763.

13. Hill, C. B., Li, Y., and Hartman, G. L. 2004. Resistance to the soybean aphid in soybean germplasm. Crop Sci. 44:98-106.

14. Hobbs, H. A., Herman, T. K., Slaminko, T. L., Wang, Y., Nguyen, B. T. McCoppin, N. K., Domier, L. L., and Hartman, G. L. 2010. Occurrences of soybean viruses, fungal diseases, and pests in Illinois soybean rust sentinel plots. Published online. Plant Health Progress doi:10.1094/PHP-2010-082701-BR.

15. Honda, K. 2001. Aphids and their transmission of viruses on soybeans in Japan. Agrochem. Jpn. 79:2-7.

16. Honda, K., Kanematsu, S., and Mikoshiba, Y. 1999. Dwarfing strain of Soybean dwarf luteovirus transmitted by Nearctaphis bakeri and Acyrthosi- 
phon pisum. Ann. Phytopathol. Soc. Jpn. 65:387.

17. Iwaki, M., Roechan, M., Hibino, H., Tochihara, H., and Tantera, D. M. 1980. A persistent aphidborne virus of soybean, Indonesian soybean dwarf virus. Plant Dis. 64:1027-1030.

18. Johnstone, G. R., and Guy, P. L. 1986. Epidemiology of viruses persistently transmitted by aphids. Proc. Workshop Epidemiology Plant Virus Diseases, IX/1-7. Int. Soc. Plant Pathol.

19. Johnstone, G. R., Liu, H.-Y., and Duffus, J. E. 1984. First report of a subterranean clover red leaf-like virus in the western hemisphere. (Abstr.) Phytopathology 74:795.

20. Kellock, A. W. 1971. Red leaf virus-a newly recognized virus of subterranean clover (Trifolium subterraneum L.). Aust. J. Agric. Res. 22:615-624.

21. Makkouk, K. M., and Kumari, S. G. 2009. Epidemiology and integrated management of persistently transmitted aphid-borne viruses of legume and cereal crops in West Asia and North Africa. Virus Res. 141:209-218.

22. McLaughlin, M. R., Damsteegt, V. D., Duffus, J. E., and Hewings, A. D. 1988. Subterranean clover red leaf (soybean dwarf)-like luteovirus found in Mississippi. (Abstr.) Phytopathology 78:1584.

23. Mikoshiba, Y., Honda, K., Kanematsu, S., and Fujisawa, S. 1991. A new strain of Soybean dwarf virus transmitted by Acyrthosiphon pisum in Japan. Ann. Phytopathol. Soc. Jpn. 57:448.

24. Phibbs, A., and Barta, A. 2009. Wisconsin Pest Survey Report: 2008 soybean virus survey. WI DATCP Pest Survey. Published online. http://pestsurvey.wi.gov/

25. Phibbs, A., Barta, A., and Domier, L. L. 2004. First report of Soybean dwarf virus on soybean in Wisconsin. Plant Dis. 88:1285.

26. Ragsdale, D. W., Voegtlin, D. J., and O'Neil, R. J. 2004. Soybean aphid biology in North America. Ann. Entomol. Soc. Am. 97:204-208.

27. Rathjen, J. R., Karageorgos, L. E., Habili, N., Waterhouse, P. M., and Symons, R. H. 1994. Soybean dwarf luteovirus contains the third variant genome type in the luteovirus group. Virology 198:671-679.

28. Schneider, W. L., Damsteegt, V. D., Stone, A. L., Kuhlmann, M., Bunyard, B. A., Sherman, D. J., Graves, M. V., Smythers, G., Smith, O. P., and Hatziloukas, E. 2011. Molecular analysis of Soybean dwarf virus isolates in the eastern United States confirms the presence of both D and Y strains and provides evidence of mixed infections and recombination. Virology 412:4654.

29. Smith, O. P., Damsteegt, V. D., Harris, K. F., and Vonder Haar, R. 1993.
Nucleotide sequence and $E$. coli expression of the coat protein gene of the yellowing strain of Soybean dwarf luteovirus. Arch. Virol. 133:223-231.

30. Smith, O. P., Durkin, S. A., Luster, D. G., McDaniel, L. L., and Damsteegt, V. D. 1998. Sequence and expression in Escherichia coli of the coat protein gene of the dwarfing strain of Soybean dwarf luteovirus. Virus Genes 17:1-

31. Smith, O. P., Hunst, P. L., Hewings, A. D., Stone, A. L., Tolin, S. A., and Damsteegt, V. D. 1991. Identification of dsRNAs associated with Soybean dwarf virus-infected soybean. Phytopathology 81:131-134.

32. Tamada, T. 1970. Aphid transmission and host range of soybean dwarf virus. Ann. Phytopathol. Soc. Jpn. 36:266-274.

33. Tamada, T. 1973. Strains of Soybean dwarf virus. Ann. Phytopathol. Soc. Jpn. 39:27-34.

34. Tamada, T. 1975. Studies on the soybean dwarf disease. Rep. Hokkaido Prefect. Agric. Exp. Stn. 25:114-144.

35. Tamada, T., Goto, T., Chiba, I., and Suwa, T. 1969. Soybean dwarf, a new virus disease. Ann. Phytopathol. Soc. Jpn. 35:282-285.

36. Tamada, T., and Kojima, M. 1977. Soybean dwarf virus. CMI/AAB Description of Plant Viruses No. 179. Commonw. Mycol. Inst./Assoc Appl. Biol., Surrey, England.

37. Terauchi, H., Kanematsu, S., Honda, K., Mikoshiba, Y., Ishiguro, K., and Hidaka, S. 2001. Comparison of complete nucleotide sequences of genomic RNAs of four Soybean dwarf virus strains that differ in their vector specificity and symptom production. Arch. Virol. 146:1885-1898.

38. Thekke Veetil, T., Hobbs, H. A., and Domier, L. L. 2009. Sequence diversity of readthrough proteins of Soybean dwarf virus isolates from the Midwestern United States. Arch. Virol. 154:861-866.

39. Thekke Veetil, T., Hobbs, H. A., Wang, Y., Kridelbaugh, D., Donnelly, J., Hartman, G. L., and Domier, L. L. 2007. First report of Soybean dwarf virus in soybean in Northern Illinois. Plant Dis. 91:1686.

40. Wallis, C. M., Stone, A. L., Sherman, D. J., Damsteegt, V. D., Gildow, F. E., and Schneider, W. L. 2007. Adaptation of plum pox virus to a herbaceous host (Pisum sativum) following serial passages. J. Gen. Virol. 88:28392845 .

41. Wang, R. Y., Kritzman, A., Hershman, D. E., and Ghabrial, S. A. 2006 Aphis glycines as a vector of persistently and nonpersistently transmitted viruses and potential risks for soybean and other crops. Plant Dis. 90:920926. 